\title{
PENGARUH EDUKASI SELF CARE BERBASIS INTERAKSI PERAWAT PASIEN TERHADAP KEPATUHAN DIET PADA PASIEN PENYAKIT GINJAL KRONIK (Di Instlasi Rawat Jalan Rumah Sakit Islam Surabaya A. Yani)
}

\author{
The Effect Of Self Care Education Based On Patient Nursing Interactions On Diet \\ Compliance In Chronic Kidney Disease Patients \\ (At the Outpatient Institution of Surabaya Islamic Hospital A. Yani)
}

\author{
Sulastri' ${ }^{1}$ Nursalam ${ }^{2}$, Puji Astuti ${ }^{3}$ \\ ${ }^{1}$ Mahasiswa Universitas Nahdlatul Ulama Surabaya \\ ${ }^{2}$ Universitas Airlangga Surabaya \\ ${ }^{3}$ Universitas Nahdlatul Ulama Surabaya \\ sulasti200470hadi@gmail.com
}

\begin{abstract}
ABSTRAK
Angka kejadian penyakit ginjal kronik meningkat dari tahun ktahun, dan merupakan salah satu masalah kesehatan yang dihadapi berbagai negara di dunia. Ketidakpatuhan diet dapat menyebabkan pasien penyakit ginjal kronik jatuh ke stadium lanjut. Tujuan penelitian ini adalah menganalisa pengaruh edukasi self care berbasis interaksi perawat pasien terhadap kepatuhan diet pada kelompok kontrol dan intervensi.

Desain penelitian ini Quasi Experiment dengan pendekatan pretest posttest with control group design. Populasinya seluruh pasien penyakit ginjal kronik di poli nefrologi Rumah Sakit Islam Surabaya A. Yani sebanyak 70 orang. Besar sampel 54 responden terbagi 27 responden kelompok kontrol dan 27 responden kelompok intervensi. Teknik sampling adalah simple random sampling. Kelompok kontrol diberikan edukasi sesuai standar Rumah Sakit, sedangkan kelompok intervensi diberikan edukasi self care selama 10-15 menit selama 4x tatap muka. Analisis data menggunakan uji Manova dengan kemaknaan $\alpha=$ 0,05 .

Hasil penelitian menunjukkan bahwa nilai Partial eta squared kepatuhan sebesar 0.953. Analisis dengan uji manova menunjukkan $p$ value $=0.000$, yang berarti ada pengaruh pemberian edukasi self care berbasis interaksi perawat pasien terhadap kepatuhan diet pada pasien penyakit ginjal kronik.

Pemberian edukasi self care dapat meningkatkan kepatuhan diet pada pasien penyakit ginjal kronik, serta menghambat progesifitas kerusakan ginjal. Perawat Poli nephrology dapat menerapkan edukasi self care sebagai bagian dari managemen daily activity pasien penyakit ginjal kronik, lebih efektif pada stadium dini.
\end{abstract}

Kata kunci: Edukasi self care, Penyakit Ginjal Kronik, Kepatuhan.

\begin{abstract}
Introduction the incidence rate of chronic kidney disease, which is one of the common health problems in the world, is increasing from year to year. Dietary can lead patients with chronic kidney disease to advanced stages. The purposed of this study was analyze the effects of self-care education on the basis of nurse-patient interaction on dietary in patients with chronic kidney disease. Methods this research quasi-experimental study used pretest-posttest control group design. It involved all patients with chronic kidney disease in the nephrology polyclinic of Rumah Sakit Islam Surabaya A. Yani totaling 70 people as the population in which 54 respondents were chosen as the samples comprising of 27 respondents assigned to control group and 27 respondents assigned to experimental/treatment group by using simple random sampling technique. The control group received education appropriate with the hospital standards, whereas the experimental group received self-care education on the basis of nurse-patient interaction for 10-15 minutes in 4 meetings. The data analysis was conducted using Manova test with the significance level of $\alpha=0.05$. Result the value of partial eta squared for dietary was 0.953 . Moreover, the results of analysis using Manova test showed that $\mathrm{p}$ value $=0.000$, describing that self-care education on the basis of nurse-patient interaction was effective on dietary in patients with chronic kidney disease. Discution and conclution self-care education on the basis of nurse-patient interaction has increased dietary in patients with chronic kidney disease, and slowed down progressive kidney damages. Therefore, the nurses in nephrology polyclinic should be able to provide selfcare education as a part of managing daily activities of patients with chronic kidney disease in early stages for more effectiveness.
\end{abstract}

Key words: self-care education, kidney disease, obedience 


\section{PENDAHULUAN}

Penyakit ginjal kronik adalah penurunan fungsi ginjal yang irreversible dan progresif dengan manifestasi klinis penumpukan sisa metabolik di dalam darah. Ginjal berperan untuk mempertahankan volume dan distribusi cairan, namun jika ginjal gagal menjalankan fungsinya maka orang tersebut akan memerlukan perawatan dan pengobatan dengan segera (Muttaqin, 2011).

Angka kejadian penyakit gagal ginjal kronik meningkat dari tahun ke tahun, dan merupakan salah satu masalah kesehatan yang dihadapi oleh berbagai negara di dunia. National Chronic Center for Chronik Disease Prevention and Health Promotion (2014) melaporkan prevalensi penderita penyakit ginjal kronik di Amerika Serikat pada tahun 2014 berjumlah sekitar 30 juta orang atau sekitar $15 \%$ dari jumlah penduduk Amerika Serikat yang dewasa, dan $52 \%$ memerlukan pelayanan hemodialisis. PGK penyebab kematian urutan ke-27 pada tahun 1990 dan meningkat menjadi urutan ke-18 pada tahun 2010, Pusat Data dan Informasi Kementerian Kesehatan RI (2017).

Studi pendahuluan yang dilakukan di poli nefrologi RS Islam Surabaya A. Yani didapatkan data bahwa penderita penyakit ginjal kronis setiap tahunnya mengalami peningkatan. Hal ini dibuktikan dua tahun yang lalu awal dibukanya poli nefrologi hanya terdapat 5 penderita dan saat ini, sampai akhir tahun 2017 penderita penyakit ginjal kronis sudah mencapai 70 penderita, 40 penderita menjalani hemodialysis dan 30 penderita menjalani rawat jalan di poli nefrologi (data rekam medik RS Islam Surabaya A. Yani, 2017). Penderita penyakit ginjal kronik sebanyak 70 penderita tersebut mereka kontrol secara rutin di poli refrologi RS Islam Surabaya A. Yani, namun masih banyak penderita yang jatuh kedalam stadium selanjutnya, bahkan tahap akhir (End State Renal Desease) (36\%), salah satu sebabnya adalah karena kurang patuhnya pada diet yang dianjurkan oleh pasien dengan penyakit ginjal kronik.

Kepatuhan penderita berarti bahwa penderita dan keluarga harus meluangkan waktu dalam menjalani pengobatan yang dibutuhkan. Seseorang yang menderita penyakit ginjal kronik harus mengikuti pengobatan, mematuhi diet (WHO, 2010).
Komplikasi baik fisik maupun psikis tentunya menjadi gangguan dalam melakukan perawatan diri secara mandiri pada pasien penyakit ginjal kronik. Pasien membutuhkan kemampuan dalam perawatan dirinya sendiri. Saat ini kemampuan self care pasien telah menjadi perhatian dunia seiring dengan peningkatan kejadian penyakit kronis, peningkatan biaya pengobatan serta tenaga educator yang tidak cukup. Self care merupakan gambaran perilaku seorang individu yang dilakukan dengan sadar, bersifat universal, dan terbatas pada diri sendiri (Weiler \& Janice, 2007 dalam Kusniawati, 2011).

Beberapa cara untuk mempertahankan fungsi ginjal untuk mencegah progresifitas dari kerusakan ginjal yakni dengan mengontrol resiko penyakit ginjal kronik dengan mengkontrol kadar gula, mengontrol tekanan darah. Melakukan pemeriksaan fungsi ginjal bagi penderita DM dengan hipertensi efektif untuk mengetahui penyakit ginjal kronik secara dini. Manajemen penyakit ginjal kronik

dengan cara pengunaan obat yang aman, pengaturan diet. Belajar tentang penyakit ginjal kronik. Semua hal-hal tersebut diatas dapat dilakukan oleh perawat dengan memberikan self care edukasi berbasis interaksi perawat dan pasien, National Chronic Center for Chronik Disease Prevention and Health Promotion (2014).

Self care dapat diartikan sebagai strategi coping seseorang supaya dapat mandiri dalam melakukan perawatan untuk dirinya sendiri sehingga gejala penyakit berkurang dan kualitas hidup meningkat, Shahram Baraz, Kourosh Zara, Hajiee Bibi Shahbazian (2017). Self care juga dapat diartikan proses penerimaan diri dengan kondisi yang ada sekarang fisik dan fisiologis baru mereka sehingga dapat beradaptasi terhadap pengobatan dan perawatan yang diperlukan, sehingga dapat mempercepat kesembuhan pasien. Edukasi self care sangat dibutuhkan untuk mengembangkan self care pasien dengan penyakit ginjal kronik sehingga kualitas hidup penderita meningkat, Farzad Poorgholami, Shohreh Javadpour, Vahid Saadatmand dan Marzieh Kargar Jahromi (2015). Penelitian ini dilakukan untuk mengetaui "Apakah ada pengaruh edukasi self care berbasis interaksi perawat pasien 
terhadap kepatuhan diet pada pasien dengan penyakit ginjal kronik di Rumah Sakit Islam Surabaya A. Yani?

\section{METODE}

Penelitian ini menggunakan rancangan penelitian quasy experiment dengan desain penelitian pretest posttest with control group design. Penelitian ini melibatkan dua kelompok subjek yaitu kelompok intervensi dan kelompok kontrol. Kelompok intervensi diberikan edukasi self care berbasis interaksi perawat pasien. Kelompok kontrol mendapatkan edukasi sesuai standart rumah sakit, (Suharsaputra, 2014). Besar sample 54 orang yang diambil dengan cara random sampling. Variabel independen yaitu edukasi self care berbasis interaksi perawat pasien dan variabel dependen yaitu kepatuhan diet.

Hasil pengambilan data dilakukan analisis deskriptif untuk variabel karakteristik responden (umur, jenis kelamin, pendidikan, dan lama menderita penyakit ginjal kronik), variabel kepatuhan pada kelompok kontrol maupun kelompok intervensi dengan menghitung mean, modus, median dan membuat distribusi frekuensi berdasarkan variabel. Analisis pada kedua kelompok baik kontrol maupun intervensi dengan menggunakan uji statistik parametrik dengan Paired sample t-Test dan Independent sample $t$-Test. Hipotesis diterima apabila nilai $\mathrm{p}<0,05$.

\section{HASIL PENELITIAN}

a. Data Umum

Karakteristik responden pada kelompok kontrol dan kelompok intervensi berdasarkan umur, jenis kelamin, pendidikan dan lama menderita penyakit ginjal kronik di Rumah Sakit Islam Surabaya A. Yani Juni - Juli $2018(\mathrm{~N}=54)$

\begin{tabular}{lllll}
\hline Karakterik & $\begin{array}{l}\text { Kelompok } \\
\text { Kontrol } \\
(\mathrm{n}=27)\end{array}$ & \multicolumn{2}{l}{$\begin{array}{l}\text { Kelompok } \\
\text { Intervensi } \\
(\mathrm{n}=27)\end{array}$} \\
\cline { 2 - 5 } & $\mathrm{n}$ & $\%$ & $\mathrm{n}$ & $\%$ \\
\hline Umur (tahun) & & & & \\
$46-55$ & 14 & 51,9 & 19 & 70,4 \\
$56-65$ & 7 & 25,9 & 2 & 7,4 \\
$66-75$ & 6 & 22,2 & 6 & 22,2 \\
Jenis Kelamin & & & & \\
Perempuan & 15 & 55,6 & 11 & 40,7 \\
Laki-laki & 12 & 44,4 & 16 & 59,3 \\
& & & &
\end{tabular}

\begin{tabular}{lllll}
\hline $\begin{array}{l}\text { Pendidikan } \\
\text { Terakhir }\end{array}$ & & & & \\
SD & 2 & 7,4 & 0 & 0 \\
SMP & 5 & 18,5 & 4 & 14,8 \\
SMA & 15 & 55,6 & 12 & 44,4 \\
Diploma/S1/S & 5 & 18,5 & 11 & 40,7 \\
2 & & & & \\
Lama PGK & & & & \\
$<1$ Tahun & & & & \\
$\geq 1$ Tahun & & & & \\
\hline
\end{tabular}

Sumber Data Primer 2018

a. Data Khusus

Pengaruh edukasi self care berbasis interaksi perawat pasien terhadap kepatuhan diet pada kelompok kontrol dan intervensi pada pasien penyakit ginjal kronik di RS Islam Surabaya A. Yani

\begin{tabular}{clccc}
\hline Kel & & Mean & SD & Sig \\
\hline I & Kontrol & 14,96 & 0,19 & 0.000 \\
& & & & \\
2 & Intervensi & 23,00 & 0,00 & 0.000 \\
I & Sebelum & 57,33 & 48,28 & 0.000 \\
& & & 4,14 & \\
& Sesudah & 105,6 & 4,21 & \\
& & 1 & & \\
K & Sebelum & 58,33 & 3,22 & 0.090 \\
& & & 3,75 & \\
& Sesudah & 61,55 & 7,52 & \\
\hline
\end{tabular}

PEMBAHASAN

Pengaruh edukasi Self Care berbasis interaksi perawat pasien terhadap Kepatuhan diet.

Pada kelompok kontrol sebelum dan sesudah pemberian edukasi yang biasanya dilakukan perawat poli nefrologi kepatuhan diet pasien tetap tidak meningkat. Penyebab tidak berubahnya kepatuhan diet pasien karena beberapa hal, ketidak jelasan informasi yang diberikan, kurang sistematisnya edukasi yang diterapkan atau kurang tepatnya metode yang digunakan, kurangnya waktu perawat saat pemberian edukasi karena edukasi diberikan sambil lalu saja mengingat pasien yang harus diberi pelayanan banyak.

Pada kelompok intervensi terdapat peningkatan kepatuhan diet, ada perbedaan yang bermakna sebelum diberi edukasi self care dengan sesudah diberi edukasi self care pada kelompok intervensi, dibandingkan kelompok kontrol yang tidak mendapatkan 
edukasi self care. Hasil pengujian hipotesis yang menyatakan bahwa edukasi self care dengan menggunakan modul dapat meningkatkan pengetauan dan pemahaman pasien dengan penyakit ginjal kronik lebih baik dibandingkan dengan pemberian edukasi yang biasa dikerjakan perawat sehari-hari, menunjukkan perlu adanya perubahan metode edukasi pada pasien.

Keperawatan mandiri menurut orem adalah kemampuan seseorang untuk dapat memenuhi kebutuhan serta mempertahankan kehidupan, kesejahteraan, kesehatan sesuai keadaannya saat ini (Alligood 2016). Pasien penyakit ginjal kronik merupakan pasien yang memiliki permasalahan yang komplek dan membutuhkan perawatan secara holistik. Edukasi self care pada pasien penyakit ginjal kronik dibutuhkan agar pasien dapat memiliki kemampuan self care secara maksimal sehingga dapat mempertahankan kualitas hidup seoptimal mungkin.

Terdapat pengaruh pemberian edukasi self care berbasis interaksi perawat pasien dalam bentuk modul terhadap kepatuhan diet disebabkan modul merupakan suatu proses yang tersistem dengan menggunakan media pembelajaran akan sangat membantu proses berfikir serta penyampaian isi materi dan pesan-pesan yang harus diperhatikan. Pendidikan terbanyak responden adalah SMA serta usia terbanyak adalah usia 46-55 tahun, sehingga pemberian edukasi self care dengan memberikan modul akan mudah diterima dan dipahami pasien. Pasien yang mempunyai pendidikan tinggi serta dewasa secara umum akan mempunyai kemampuan dalam merespon stimulus lingkungan secara cepat dalam upaya membentuk persepsi yang positif. Edukasi self care berbasis interaksi perawat pasien dalam bentuk pemberian modul dapat dipelajari keluarga dirumah supaya keluarga dapat mengontrol dan membantu untuk menginggatkan serta memberi informasi mengenai aturan pembatasan cairan maupun aturan diet pasien, serta dapat memberikan upaya pencegahan bagi keluarga yang beresiko, karena selama pasien kontrol ke poli nefrologi selalu didampingi keluarga. Penatalaksanaan pelayanan berpusat pada keluarga mempunyai banyak keuntungan yaitu tidak menambah beban keluarga justru akan membantu menyelesaikan permasalahan-permasalahan kesehatan keluarga yang sedang mereka hadapi serta mengupayakan keluarga yang sehat supaya dapat mempertahankan status kesehatannya.

Pada penelitian ini edukasi self care berbasis interaksi perawat pasien pada materi tentang diet juga berkolaborasi dengan tim gizi Rumah Sakit Islam Surabaya A. Yani peneliti memberikan penjelasan masalah makanan yang diperbolehkan dan yang tidak diperbolehkan dan makanan yang harus dibatasi serta akibat yang bisa terjadi jika pasien ginjal kronik tidak mematuhi diet (Almatsier, 2010).

Perbedaan kepatuhan pada kelompok kontrol dan kelompok intervensi yaitu pada kelompok kontrol kepatuhan sebelum pemberian edukasi maupun sesudah pemberian edukasi tidak ada perbedaan, kepatuhan kelompok kontrol sama sebelum maupun sesudah pemberian edukasi yang biasanya dilakukan di ruang poli nefrologi Rumah Sakit Islam Surabaya A. Yani. Kepatuhan pada kelompok intervensi sebelum dan sesudah pemberian edukasi selfcare berbasis interaksi perawat pasien pada pasien penyakit ginjal kronik meningkat. Hal ini sesuai dengan penelitian Dewi (2014) \& Febrianti (2013) yang mengatakan bahwa pemberian edukasi memberikan pengaruh yang signifikan terhadap kepatuhan pasien minum obat hipertensi, sebelum dan sesudah pemberian edukasi. Penelitian Rahayu (2018) yang mengatakan ada pengaruh pemberian edukasi suportif terhadap pengontrolan tekanan darah pada pasien dengan hiprtensi. Penelitian Megan (2016) mengatakan ada pengaruh pemberian edukasi dalam bentuk pemberian motivasi terhadap kemampuan perawatan diri pada pasien penyakit jantung. Pernyataan senada juga diungkapkan oleh Riegel (2015) yang mengatakan pemberian edukasi yang menekankan motivasi pada pasien lebih efektif dibanding dengan pemberian edukasi yang lain dalam hal meningkatkan perawatan diri pada pasien penyakit jantung sehingga gejala dan kualitas hidup pasien dengan penyakit jantung meningkat. Pada penelitian yang dilakukan oleh Jahromi (2015) mengatakan bahwa pemberian edukasi self care efektif untuk meningkatkan kepercayaan diri pasien gagal ginjal yang menjalani 
Hemodialisis sehingga memperlancar pemberian terapi pada pasien.

\section{KESIMPULAN}

Berdasarkan penelitian yang telah dilakukan tentang pengaruh edukasi selfcare berbasis interaksi perawat pasien terhadap kepatuhan diet di Rumah Sakit Islam Surabaya A. Yani dapat disimpulkan bahwa: Edukasi selfcare berbasis interaksi perawat pasien meningkatkan kepatuhan diet pasien penyakit ginjal kronik.

\section{SARAN}

Pihak Rumah Sakit dapat memberikan kebijakan tentang pemberian edukasi selfcare berbasis interaksi perawat pasien pada pasien ginjal kronik di poli nefrologi di Rumah Sakit Islam Surabaya A. Yani . Hal ini penting dilakukan mengingat pasien penyakit ginjal kronik memerlukan perawatan yang lama dan memiliki banyak masalah kesehatan yang harus dipecahkan. Sehingga pasien penyakit ginjal kronik mampu merawat dirinya sendiri dengan baik dan benar dengan kondisi dan keadaan yang ada saat ini. Edukasi selfcare berbasis interaksi perawat pasien akan lebih optimal jika dilakukan secara sistematis dan kontinyu serta mendapat dukungan dari management.

\section{DAFTAR PUSTAKA}

Ahmadi, A. 2009. Psikologi Sosial. Jakarta : Rineka Cipta

Anggraini, Dian. 2008. Perbandingan Kepuasan Pasien Gakin dan Pasien Umum di Unit Rawat Inap RSUD Budhi Asih Tahun 2008. Skripsi. Program sarjana Fakultas Kesehatan Masyarakat Universitas Indonesia, Depok.

Astuti. 2009. Bahan dasar untuk pelayanan konseling. Jakarta; Grasindobaradero

Bertenz, K. (2006). Psikoanalisis Sigmund Freud. Jakarta: Gramedia Pustaka Utama.

Boykin, A and Schoenhofer, S.O. Nursing as caring: A model for transforming practice. New York : National League for Nursing, 2001.
Burnard Philip \& Morrison Paul. 2009. Caring \& Communicating alih bahasa Widyawati. Edisi 2. Jakarta: EGC.

Carpenito, J. Lynda. 2009.. Diagnosa Keperawatan : Aplikasi pada Praktik. Klinis. Jakarta : EGC

Fahriani,Rini 2011, Analisis Budaya Organisasi yang Berhubungan dengan Perilaku Caring perawat pelaksana di Ruang Rawat inap RSUD PROF.DR.H.aloei Saboe kota Gorontalo, $\quad$ http://lontar.ui.ac.id Diakses tanggal 27 Januari 2018,

Jane, SL. 2002. Interventions to Decrease Family Anxiety. Critical Care Nurse, 22(6),61-5.

http://search.proquest.com/doc.

Diakses tanggal 26 Januari 2018.

Kaplan, H.I. Saddock, B.I., 2007. Mood Disorder. In Synopsis of Psychiatry. Baltimore: William and Wilkins 2007, 288-303

Kusmiran, Eny. 2015. Soft Skills Caring Dalam Pelayanan Keperawatan. Jakarta: Trans Info Media.

Nursalam. 2015. Manajemen Keperawatan. Jakarta: Salemba Medika

Potter, A \& Perry, G. 2005. Buku Ajar Fundamental Keperawatan: Konsep, Proses dan Praktik Edisi 4 Vol. 1. Jakarta: EGC.

Potter. A. Patricia \& Perry. G. Anne. 2009. Buku Ajar Fundamental Keperawatan. Jakarta : EGC.

Sani Ibrahim, Ayub. 2012. Panik Neurosis dan Gangguan Cemas. Edisi pertama. Tangerang: Penerbit Jelajah Nusa.

Savitri Ramaiah. 2003. Kecemasan Bagaimana Mengatasi Penyebabnya. Jakarta : Pustaka. Populer Obor

Stuart, G.W. 2013. Buku Saku Keperawatan Jiwa Edisi 5. Jakarta: EGC. 
Stuart, G.W. \& Sunden, J.2009. Principles and practice of psychiatric nursing. St Louis: Mosby.

Suliswati. 2005. Konsep Dasar Keperawatan Jiwa. Jakarta : EGC

Suryanti, Netty. 2002. Faktor-Faktor Yang Berhubungan Dengan Lamanya Waktu Proses Pendaftaran Pasien Rawat Inap Di Rumah Sakit Pondok Indah. Tesis. Program Pasca Sarjana Fakultas Kesehatan Masyarakat Universitas Indonesia, Depok.

Swanson. 1991. A deconstruction of caring. Journal of Advanced Nursing,

Watson, Jean. 2008. Nursing The Philosophy and Science of Caring, Revised Edition. Colorado: University Press of Colorado.

Watson, Jean. 2009. Assessing and measuring caring in nursing and health science. New York : Springer Publishing Company.

Wulan \& Hastuti, M. 2011. Pengantar Etika Keperawatan. Jakarta: Prestasi Pustaka. 